\title{
Adapting to the impacts of climate change in the sub-humid zone of Burkina Faso, West Africa: Perceptions of agro-pastoralists
}

\author{
Sophie Agnes Kima ${ }^{*}$, A. A. Okhimamhe ${ }^{1}$, Andre Kiema², Nouhoun Zampaligre ${ }^{3}$ and Isaiah Sule ${ }^{1}$
}

\begin{abstract}
This study examined the impact of climate change on pastoral livestock in Boulgou Province located in the sub-humid zone of Burkina Faso. We analysed the annual rainfall and temperature data from 1980 to 2012 using both Mann-Kendall's statistical test to show the long-term annual trends and Standardised Anomaly Index (SAI) to evaluate inter-annual rainfall fluctuations. We also conducted household interviews with 248 respondents to analyse agro-pastoralists' perceptions of climate change and variability, its impacts on livestock production and their acceptance of adaptation measures. A binary regression model was employed to identify the most important factors affecting agro-pastoralists' decisions to adopt specific adaptation measures. Within the period of study, the annual rainfall showed an upward trend, with high inter-annual variability and $818.9 \mathrm{~mm}$ of mean annual rainfall. Additionally, the annual minimum and maximum temperatures showed a statistically significant upward trend, with a rate of change of $0.20{ }^{\circ} \mathrm{C}$ and $0.27{ }^{\circ} \mathrm{C}$ per decade. The results of the household interviews indicated that most of the respondents (73.4\%) observed temperature changes compared with rainfall amount (1.2\%). To adapt to these changes, they have already adopted some adaptation measures that include the use of crop residue and herd destocking. Other less popular but innovative adaptation measures such as haymaking and use of concentrate livestock feeds could be promoted effectively under a comprehensive climate change adaptation action plan within a reviewed National Policy for Sustainable Livestock Development. This case study is one of the platforms through which poor agro-pastoralists' perception and recommendations can be accommodated in this proposed multi-stakeholder policy review.
\end{abstract}

Keywords: Agro-pastoralists; Climate change perception; Mann-Kendall's test; Sub-humid zone of Burkina Faso; Climate change action plan

\section{Background}

The irrevocable nature of climate change (IPCC 2007) and overcoming the challenges associated with the assessment and prediction of its impacts on various sectors and regions is very critical. Although the vulnerability of the largely agrarian economy of most countries in the Sahel region of West Africa has been documented (Barbier et al. 2009; ECOWAS-SWAC/OECD/CILSS 2008; Kandji et al. 2006; Lodoun et al. 2013), most

\footnotetext{
* Correspondence: kimagnesi@yahoo.fr

${ }^{1}$ Master Research Programme on Climate Change and Adapted Land Use, West African Science Service Center on Climate Change and Adapted Land Use, Federal University of Technology, Gidan Kwano Campus, PMP 65, Minna, Niger State, Nigeria

Full list of author information is available at the end of the article
}

climate change models predict increasing temperature while that of rainfall is less certain (Sarr 2012). This emphasises the need for sub-regional empirical research and impact assessment studies, which could serve as the backbone for policy formulation and implementation on crop and livestock production in the agricultural sector. In comparison with crop production, however, climate change impacts on livestock production have received less attention (McCarthy et al. 2001; Seo and Mendelsohn 2006), despite the fact that the latter relies heavily and indirectly on feed resources for sustainability (Thornton et al. 2007). Galvin et al. (2004) and Thornton et al. (2007) discussed the major difference in the livestock production systems in low- and high-income countries and highlighted the consequences of this difference 
on livestock. Climate variability and change is expected to continue affecting livestock production systems in all parts of the world, including the rural poor who depend on livestock. There is a critical need to improve adaptive capacity through people-centred government interventions backed by enabling policies.

Burkina Faso, like the other Sahel countries in West Africa, relies heavily on its agricultural sector through crop and livestock production, which jointly contributed $30 \%$ to the country's GDP. In 2012, the livestock sector accounted for $11 \%$ of the country's GDP, and this increased by $4.2 \%$ in 2013 (AfDB/OECD/UNDP, 2014). However, sustenance of the industry depends on adapting and adjusting its practices to the changing climate patterns. This adaptive capacity is limited, judging by the persistently low ranking of Burkina Faso's Human Development Index (HDI), which rose from 0.321 in 2005 to 0.388 in 2013. Yet, this was still lower than the average of 0.493 and 0.502 for countries within the same category in sub-Saharan Africa (AfDB/OECD/UNDP, 2014). An understanding of the adaptive capacity of livestock farmers starts with assessing the perception of the problem and solution by stakeholders (Adesina and Zinnah 1993), and this includes their understanding of and support for policies that address the problem and also their willingness to change behaviour (Lorenzoni and Pidgeon 2006). Consequently, recent studies on adaptation measures have included the perception of climate change as a basic requirement for selecting people-centred adaptation measures (Ouédraogo et al. 2010; Silvestri et al. 2012).

In Burkina Faso, results from studies by Ouédraogo et al. (2010), Kiema et al. (2013) and Zampaligré et al. (2013) indicate that farmers are partially aware of climate change. Nevertheless, there is a need for a comprehensive understanding of the local context of climate change in order to improve the adaptive capacity of rural livestock farmers. It suffices to add that the traditional indicators that these groups of farmers depend upon for information were no longer reliable. Additionally, previous climate change adaptation studies have focused on the Sahel regions of the country. Such studies are nonexistent for the sub-humid zone.

In order to fill this gap, this paper focused on analysing the observed changes in climate patterns as perceived by Sahel transhumant pastoralists in Boulgou Province that have also embraced sedentary farming. Boulgou Province was previously unsuitable for livestock farming because of the prevalence of tsetse flies. However, since the eradication of these flies coupled with government efforts to create pastoral zones, agro-pastoralism has become a common practice. Thus, this study is very significant because we sought to first assess the magnitude and trends of the changing climate pattern in the subhumid zone of Burkina Faso. Second, we examined agro- pastoralists' perception of changing climate patterns and their impacts on the livestock sector. Third, we identified the best adaptive practices and presented policy challenges and opportunities for their implementation at larger scale for more resilience to climate change and variability.

\section{Study area}

The province of Boulgou in Burkina Faso lies between longitude $0^{\circ} 02^{\prime}$ east and $0^{\circ} 54^{\prime}$ west and latitude $10^{\circ}$ $54^{\prime}$ and $11^{\circ} 58^{\prime}$ north. It is the fifth largest province, occupies an area of approximately $6,520 \mathrm{~km}^{2}$ (about $3 \%$ of the country) and has an estimated population of 661,928 (INSD Institut National des Statistiques et de la Demographie 2013). The province of Boulgou is located in the Sudano-Sahelian phyto-geographical zone and is characterised by two distinct wet (June-September) and dry seasons (November-May). The mean annual rainfall varies between 750 and 1,300 mm per year, while the mean temperature is approximately $28{ }^{\circ} \mathrm{C}$ (MEF Ministère de l'économie et de finances 2002). The province is drained mainly by two perennial rivers, the Nakambe and Nazinon (Red and White Volta) rivers. The Nakambe river has one of the largest hydro-agricultural and hydroelectric reservoirs in the country called the Bagré reservoir.

Until recently, the Nakambe riverside was poorly inhabited due to high risks of onchocerciacis (river blindness) and trypanosomiasis (sleeping sickness), but the completion of Bagré dam attracted settlers from the northern and western provinces. Boulgou has a generally flat terrain that lies between 270 and $300 \mathrm{~m}$ above sea level with isolated hills rising between 30 and $50 \mathrm{~m}$ above this flat plain. The soils in this plain are mainly the leached ferruginous soils, which have poor water retention capacity and are covered by bushes and thorny shrubs. However, the vertisols found along the riverbeds are used for rice cultivation. The most important economic activity in the province is agricultural production, which includes animal husbandry. Boulgou has two grazing reserves in Nouhao and Doubegue, and an agropastoral zone in Sablogo, where mostly Zebu hunchback cattle (Bos indicus) graze the fields alongside thousands of goats and donkeys. Figure 1 shows the study area.

\section{Materials and methods \\ Data used}

The study utilised climate and household survey data. Climate data consisted of daily rainfall amount, and minimum and maximum temperature data for the period from 1980 to 2012. These were obtained from the official source of climate data in Burkina Faso, General Directorate of Meteorology of Burkina ('Direction Générale de la Météorologie du Burkina') based in Ouagadougou. A household survey was conducted in four villages, namely, Malinga-Nagsore (Tenkodogo 


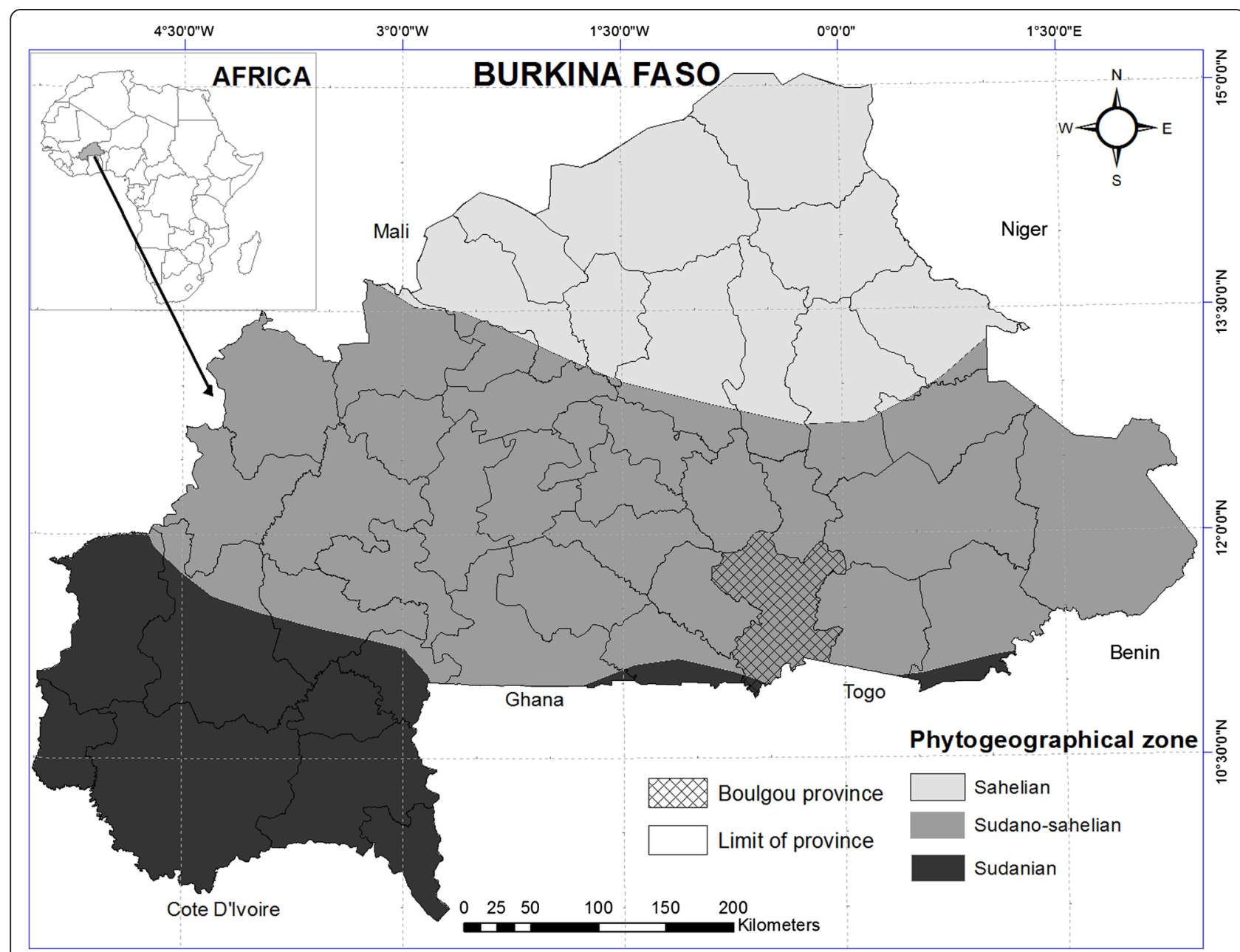

Fig. 1 Location of the selected districts in Boulgou Province of Burkina Faso (source: Institut Geographique du Burkina Faso)

district), Sanogo (Garango district), Loaba (Bittou district) and Benya (Zabre district). This selection was based on three specific criteria:

(i) the frequency of occurrence of conflict over land use;

(ii) the absence of pastoral zones: None of the villages selected have pastoral zones; and

(iii) the geographical location of the villages: MalingaNagsore and Sanogo are in the North and the other villages are in the South.

A total of 248 households were selected for the survey. For each village, the respondents constituted $10 \%$ of the number of households. By implication, in MalingaNagsore, Sanogo, Loaba and Benya, the number of households sampled was 58, 63, 70 and 57, respectively. The choice of respondents was based on livestock ownership (.i.e. minimum of five cattle and five goats/sheep) and respondents' age ( $\geq 40$ years). The assumption is that inhabitants $\geq 40$ years old constitute less than $30 \%$ of the population of Burkina Faso, had experienced the droughts of the 1970s or 1980s and could provide relatively accurate information.

\section{Data analyses}

\section{Analyses of temperature and rainfall data}

The software RClimDex, which was downloaded from http://etccdi.pacificclimate.org, was used to assess the quality of the climate data before computing their mean annual values using INSTAT (v3.36) statistical software. These values were used in computing temperature and rainfall anomalies. To evaluate the inter-annual variability of rainfall in the study area within the period under consideration, the Standardised Anomaly Index (SAI) of rainfall was calculated. According to Hadgu et al. (2013), this index is used as a descriptor of rainfall variability, and it indicates the number of standard deviations that a rainfall event deviates from the mean value under consideration. It is also used to determine dry and wet years. Positive SAI values indicate above mean annual rainfall, and negative 
SAI values indicate below mean annual rainfall. SAI is calculated as:

$$
\mathrm{SAI}=\frac{(x-\mu)}{\delta}
$$

where $X$ is annual rainfall total, $\mu$ is the mean of the entire series, and $\delta$ is the standard deviation from the mean of the series (Hadgu et al. 2013).

Daily rainfall data were also used to calculate the onset $(X)$ and cessation dates $(Y)$ in addition to the length of the rainy season or LRS $(Z)$ and the number of rainy days. To define the onset and cessation dates of rain, respectively, the methods used by Somé and Sivakumar (1994) and Maikano (2006) were adopted. The length of the rainy season was calculated as the difference between the onset and cessation dates. The number of rainy days within the rainy season was determined by adding the number of days with rainfall higher than $0.85 \mathrm{~mm}$ from 1 April to 31 October. The threshold value of rainfall amount required for a day to be counted as rainy day in West Africa is $0.85 \mathrm{~mm}$, according to Garbutt et al. (1981).

\section{Climate extreme indices and trend analysis}

The climate indices computed in this study show the frequency and duration of climate extremes as defined by Zhang and Yang (2004). Table 1 shows the seven climate indices used in computing rainfall and temperature values using RClimDex software. Both rainfall and temperature data were subjected to quality control (QC) which is a necessary step prior to the determination of the climate indices (Aguilar et al. 2009). The aim is to first detect errors in data input (such as negative value of rainfall, minimum temperature superior to maximum temperature) and also to identify outliers. Outliers are daily values outside a threshold of the mean value for that particular day plus/minus the standard deviations defined by the user (Aguilar et al. 2009).

The trend of rainfall and temperature descriptors and times series of the indices was computed based on the Mann-Kendall (MK) test using Addinsoft's XLSTAT software. For this study, the statistically significant trend was reported at the $95 \%$ confidence level (two-tailed test). Mann-Kendall's test is a non-parametric method used to test climatological data (Ly et al. 2013; Safari 2012), and studies have shown that it is the most appropriate statistical tool for the analysis of changes in climatological time series or for the detection of abrupt climate change (Klein Tank et al. 2009; Safari 2012). The MK test examines if a random variable monotonically increases or decreases with time or not (Jain and Kumar 2012; Karabulut et al. 2008; Safari 2012) and the data used may or may not be normally distributed, which makes it particularly appropriate for use with climate data (Karabulut et al. 2008). The magnitude of the trend is given by Sen's slope estimator test. This method is preceded by calculating the slope as a change in measurement per change in time, and the equation is given as follows:

$$
q_{i}=\frac{x_{j}-x_{k}}{j-k} \cdots i=1, \ldots, N
$$

where $Q=$ slope between data points $x_{j}$ and $x_{k}$, and $x_{j}$ and $x_{k}$ are data measurement at times $j$ and $k$, respectively $(j>k)$. The median of $N$ values of $Q_{i}$ is Sen's estimator of slope (Nenwiinia and Kabanda 2013).

\section{Household survey}

The household survey data were analysed using the PASW Statistical Package software (IBM, SPSS Statistics version 22). Cross-tabulation descriptive analyses and non-parametric Kruskal-Wallis analyses were performed. A binary logistic regression model was employed to show factors affecting the choice of adaptation measures used by the farmers in the study area. The model is computed from:

$$
P_{i}=\frac{\exp \left(\beta_{0}+\beta_{1} x_{i}\right)}{1+\exp \left(\beta_{0}+\beta_{1} x_{i}\right)}
$$

where $P_{i}$ is the probability of an event occurring for an observed set of variables $x_{i}$ (i.e. the probability that the farmers adopt a specific adaptation measure), $\beta_{0}$ is the

Table 1 Definition of temperature and rainfall indices selected from Zhang and Yang (2004)

\begin{tabular}{llll}
\hline Elements & Index & Descriptive names & Definition \\
\hline Tn & Tn10P & Cool night frequency & Percentage of days with TN $<$ 10th percentile of 1980 to 2012 \\
Tn & Tn90P & Warm night frequency & Percentage of days with TN $>90$ th percentile of 1980 to 2012 \\
Tx & Tx10P & Cool day frequency & Percentage of days with TX $<10$ th percentile of 1980 to 2012 \\
Tx & Tx90P & Warm night frequency & Percentage of days with TX $>90$ th percentile of 1980 to 2012 \\
Rainfall & PRCPTOT & Annual total rainfall & Annual total PRCP in wet days (RR $>1 \mathrm{~mm})$ \\
Rainfall & R5-days & Maximum 5 days precipitation & Maximum 5 days precipitation \\
Rainfall & R99P & Extremely wet days & Annual total PRCP when RR $>$ 99th percentile \\
\hline
\end{tabular}

$\mathrm{Tn}$ and $\mathrm{Tx}$ are the minimum and maximum temperatures, respectively 
intercept, and $\beta_{1}$ is the coefficients of the explanatory variables $x i$. In this study, the variables used were household size, herd size, age and the level of education of the head of household.

\section{Results and discussion}

Analyses of climate parameters in the study area (1980 to 2012)

\section{Temperature trend}

The mean annual minimum and maximum temperatures for Boulgou Province from 1980 to 2012 were $22.1^{\circ} \mathrm{C}$ and $34.4{ }^{\circ} \mathrm{C}$, respectively. In our study area, most of the hottest years were obtained after 2000 , and these were $2005\left(35.2{ }^{\circ} \mathrm{C}\right), 2006,2009,2004\left(34.9{ }^{\circ} \mathrm{C}\right)$, and 2003, $2002\left(34.8{ }^{\circ} \mathrm{C}\right)$. This reinforced results of other studies which have shown that most of the hottest years recorded in the history of instrumental temperature data collection occurred after 2000 (JMA Japan Meteorological Agency and JMA Japan Meteorological Agency 2011; NASA 2011; NOAA 2011). Further analysis showed a significant upward trend (Fig. 2) at a $95 \%$ confidence level $(p<0.001)$ and a rate of increase equal to $0.20{ }^{\circ} \mathrm{C}$ and $0.27{ }^{\circ} \mathrm{C}$ per decade, respectively (Table 2 ). The result depicted an increase of $+0.66{ }^{\circ} \mathrm{C}$ and $+0.89{ }^{\circ} \mathrm{C}$ from 1980 to 2012 for maximum and minimum temperatures, respectively. These corroborate the results that reported an increase in temperature between $+0.2{ }^{\circ} \mathrm{C}$ and $+0.8{ }^{\circ} \mathrm{C}$ since the end of the 1970s in West Africa (ECOWAS-SWAC/OECD/CILSS 2008), and $+0.29{ }^{\circ} \mathrm{C}$ and $+0.30{ }^{\circ} \mathrm{C}$ per decade globally between 1979 and 2004 (Vose et al. 2005). In addition, the result implied that the minimum temperature is increasing slightly faster than the maximum temperature. This finding is similar to the results of other studies in West Africa (ECOWAS-SWAC/OECD/CILSS 2008; Ly et al. 2013).
For the temperature indices computed using RClimdex software, the frequency of warm days and nights showed an increasing trend with Sen's slope values being 3.07 and 1.54 per decade, at a significance level of $p<0.05$ (Table 2). Also, Sen's slope values showed a significant decrease in the frequency of the cool days $(-2.04)$ and nights $(-1.85)$ per decade, thus indicating that warm days and nights had increased by 11.2 and 5.6 days per decade, while cold days and nights had decreased by 7.4 and 6.8 days per decade. This trend agrees with findings in Southern and West Africa (New et al. 2006) and most of West African countries from 1960 to 2010 (Ly et al. 2013). Some effects of temperature increase on livestock include reduced animal milk yield, body weight and reproductive performance (Scholtz et al. 2013); increase in vector-borne diseases (Pinto et al. 2008); reduced fodder yield (Thornton et al. 2009); and increase in evapotranspiration and the possibility of migration and conflicts between livestock and crop farmers, with the consequent economical, physical and psychological costs (Sirohi and Michaelowa 2007).

\section{Rainfall trend}

Rainfall in Boulgou Province has varied substantially during the past three decades (Fig. 3a) with a mean annual rainfall of $818.9 \mathrm{~mm}$ and standard deviation of $144.5 \mathrm{~mm}$. The Mann-Kendall test on the data showed a non-significant positive trend depicting a very slight increase in the rainfall amount (Table 3). This confirmed the results from studies conducted by Lodoun et al. (2013) and Wang and Gillies (2011) who reported rainfall recovery, since 1990, in most of the Sahel region. The increase in rainfall in the Sahel is accounted for by the intensification of both the tropical easterly jets (TEJ) and African easterly jets (AEJ), which are known to induce wet anomalies (Wang and Gillies 2011).
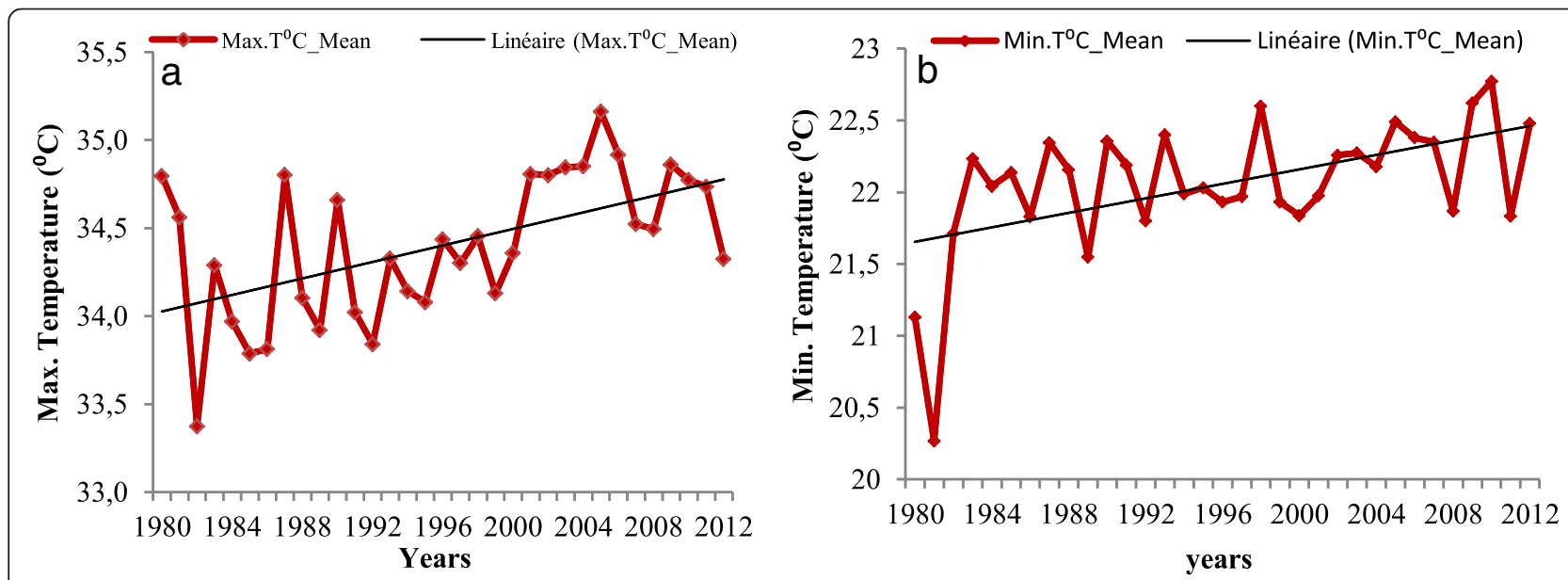

Fig. 2 (a) Variation of mean annual maximum temperature (mean $=34.4{ }^{\circ} \mathrm{C}, \mathrm{SD}=0.41^{\circ} \mathrm{C}$ ) and (b) mean annual minimum temperature (mean $=22.1^{\circ} \mathrm{C}$, $\mathrm{SD}=0.46^{\circ} \mathrm{C}$ ) of Boulgou Province (1980 to 2012). The trend line shows gradual increase in both maximum and minimum temperatures in 1980 to 2012 
Table 2 Mann-Kendall results for temperature indices (1980 to 2012) in Boulgou Province

\begin{tabular}{|c|c|c|c|c|c|c|}
\hline Elements & Descriptive names & Mean & Standard deviation & Mann-Kendall tau & $p$ value & Sen's slope \\
\hline TMAX mean & Mean annual maximum temperature & 34.4 & 0.4 & 0.336 & $0.006^{*}$ & 0.02 \\
\hline TMIN mean & Mean annual minimum temperature & 22.1 & 0.5 & 0.411 & $0.001^{*}$ & 0.027 \\
\hline TX10P & Cool day frequency & 10.1 & 3.7 & -0.313 & $0.011^{*}$ & -0.204 \\
\hline TN10P & Cool night frequency & 10.6 & 7.0 & -0.277 & $0.025^{*}$ & -0.185 \\
\hline TX90P & Warm day frequency & 9.8 & 5.4 & 0.380 & $0.002^{*}$ & 0.307 \\
\hline TN90P & Warm night frequency & 9.8 & 4.8 & 0.231 & $0.041^{*}$ & 0.154 \\
\hline
\end{tabular}

*Trend is statistically significant at $p<0.05$

The computed SAI confirmed the high variability of rainfall patterns that are quite often accentuated with positive and negative anomalies (Fig. 3b). Substantial negative anomalies occurred in 1984 and 1990, 1993 and 2002, when the calculated indices were between -1.5 and -1.6 , which signify relatively dry years. PANA (2007) reported these years as drought years in Burkina Faso. Conversely, substantial positive anomalies occurred in 1989, 1994, 2007, 2008 and 2009 with SAI between +1.5 and +2.2 , and the highest index occurred in 2009.

Within the period under consideration, 2009 was the wettest year with the worst floods in Burkina Faso. Although the trend from 1980 and 2012 is not statistically significant, it is noteworthy that the unusually wet years between 2007 and 2010 coincided with the period of high temperature anomalies globally. This may be explained by regional- and global-scale patterns of seasurface temperature (SST) that modulate the mesoscale convective systems as demonstrated by statistical analyses (Folland et al. 1986) and the use of models (Giannini et al. 2003). It has also been linked to variations in Sahelian rainfall on multi-year to decadal timescales throughout the twentieth century. An earlier study by Haarsma et al. (2005) linked the increase in Sahelian rainfall with the increase in surface air temperature over the Sahara, which, in turn, lowers the mean surface low pressure over this area.

Table 3 showed that the cumulative rainfall of extremely wet days and the intensity of rainfall had increased within the period of study. Previous studies in West African countries by Sarr (2012) and Ly et al. (2013) demonstrated that extreme rainfall was more frequent during the last decade compared to the period 1961 to 1990 . In addition to the multi-decade variability of rainfall, the increasing extreme climate events have negative consequences on the management of livestock production.

\section{Variability of onset, cessation, length of the rainy season and number of rainy days}

Two very important rainfall characteristics that affect agricultural activities are the onset and cessation of the rains. In the last 33-year period covered by the study, the mean onset occurred on 9 June with a standard deviation of 18 days (Table 4). Sarr et al. (2011) and Kiema et al. (2013) reported similar mean onset dates of 10 June

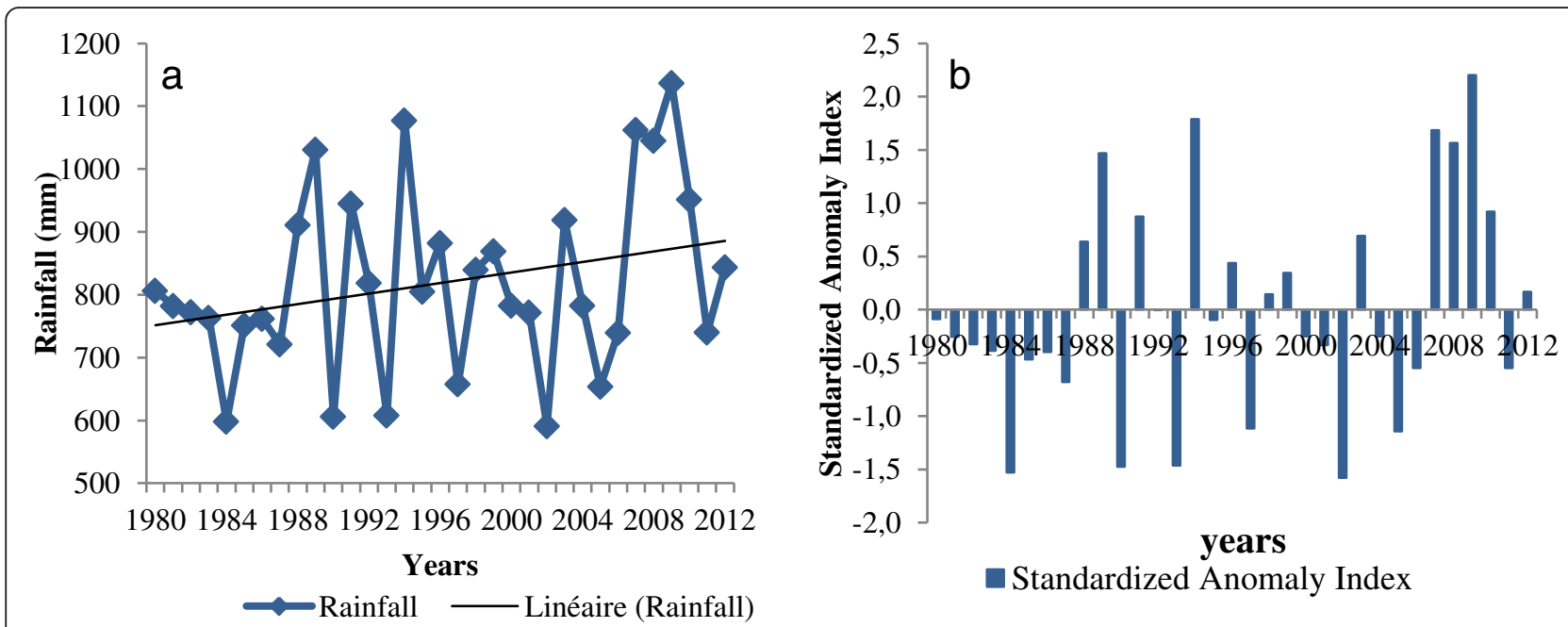

Fig. 3 (a) Mean annual rainfall amount (mean $=818.9 \mathrm{~mm}, \mathrm{SD}=144.5 \mathrm{~mm}$ ) and (b) standardized time series of rainfall for Boulgou Province (1980 to 2012). Note that the inter-annual variability of rainfall was generally high within the study period. However, below normal rainfall was recorded in 1980 to 1988, while the reverse was the case in 2007 to 2010 
Table 3 Mann-Kendall results for rainfall indices (1980 to 2012) in Boulgou Province

\begin{tabular}{|c|c|c|c|c|c|c|}
\hline Elements & Descriptive names & Mean & Standard deviation & Mann-Kendall tau & $p$ value & Sen's slope \\
\hline PRCPT & Annual total rainfall & 818.9 & 144.0 & 0.140 & $0.261^{*}$ & 3.19 \\
\hline R5days & Maximum 5 days precipitation & 113.8 & 25.6 & 0.167 & $0.179^{*}$ & 0.705 \\
\hline R95P & Extremely wet days & 168.2 & 99.3 & 0.208 & $0.092^{*}$ & 3.741 \\
\hline
\end{tabular}

*Trend not statistically significant at $p=0.05$

and 18 June for Fada N'Gourma and Diapaga in the eastern part of Burkina Faso. On the average, cessation of rains within the study area occurred on 7 October, with a standard deviation of 9 days. The cessation dates were late with a non-significant positive trend. The mean length of rainy season (LRS) had increased slightly to 119 days, with a high standard deviation of 21 days. The lowest and highest LRS were between 76 days (in 2005) and 166 days (in 1996). This high inter-annual variability of the seasonal distribution of rainfall has negative effects on the ability to accurately predict its onset and cessation dates. The LRS is an important factor that influences the availability of fresh fodder for livestock (such as Mucuna spp. Stylosanthes spp. and Vigna spp.) that thrive during the rainy season. This situation is expected to worsen with the changing climate patterns and as livestock farmers seek alternative fodder crop types to cultivate.

\section{Household survey \\ Socio-economic characteristics of interviewed agro-pastoralist households}

Analysis of respondents in the survey showed the following socio-economic characteristics: gender (94\% were males), average age (55 years), no formal education (96\%), natives (82.3\%), average household size (18), animal husbandry as the main source of income (52\%), herd size ( $85 \%$ of the respondents have less than 30 cattle, sheep and goats), membership of herders' organisations (21 \%) and membership of crop farmers' organisations (4\%). These characteristics imply that most of the respondents are illiterates and have poor access to information

Table 4 The respondents' perception of climate variability and change $(n=248)$

\begin{tabular}{llc}
\hline Variables & Increased or earlier (\%) & Decreased or late (\%) \\
\hline Temperature & 73.4 & 25.4 \\
Rainfall amount & 1.2 & 97.2 \\
Rainfall intensity & 6.9 & 91.5 \\
Rainfall frequency & 1.2 & 95.2 \\
Occurrence of flood & 28.6 & 49.2 \\
Occurrence of drought & 85.5 & 11.3 \\
Onset of rains & 33.5 & 63.7 \\
Cessation of rains & 90.3 & 4.8 \\
Length of rainy season & 4 & 91.1 \\
\hline
\end{tabular}

other than the local knowledge obtained from experience. Additionally, their main source of livelihood is climate dependent, and this exposes their income to vagaries of climate.

\section{Agro-pastoralists' perception of climate variability and change}

Most of the respondents in Boulgou Province had perceived a change in climate through their observations on changes in temperature and rainfall within the last 30 years (Table 4 ). The findings of the interviews were similar to those of Akponikpè et al. (2010), Ouédraogo et al. (2010) and Allé et al. (2013). These include respondents' perception of a hotter climate (73\%); a decrease in rainfall amount (97\%), intensity (92\%) and frequency (92\%); delayed onset (63\%); and early cessation (90\%) of the rainy season. However, the slight increase in rainfall was not perceived by the respondents. This difference could be explained by the high inter-annual rainfall variability. The second inconsistency between respondents' perception and climate data was on the cessation of the rainy season, which was perceived as being early. In general, the respondents reported that the climate had changed for the worse. According to Akponikpè et al. (2010), farmers do not perceive climate in meteorological terms but as it affects agricultural activities. This may explain the disagreement between some respondents' perceptions and scientific evidence. Evidently, there is always a need to connect traditional knowledge derived from the daily experiences of the agro-pastoralists with climate data through enlightenment and provision of climate information.

\section{Impacts of climate variability and change on livestock}

Agro-pastoralists' responses on the impacts of the changing climate pattern on the livestock are presented in Fig. 4. The result showed that $97 \%, 94 \%$ and $89 \%$ of the respondents had observed a reduction in crop yield and forage quantity and quality, respectively. Additionally, $90 \%$ had observed that water availability had reduced. Furthermore, the reduction of income and increase in conflict between livestock and crop farmers were reported by 89 and $78 \%$ of the respondents, respectively. Concerning livestock production, 79, 87 and $84 \%$ of the respondents reported that animal fertility and milk and meat production had reduced. In addition, 


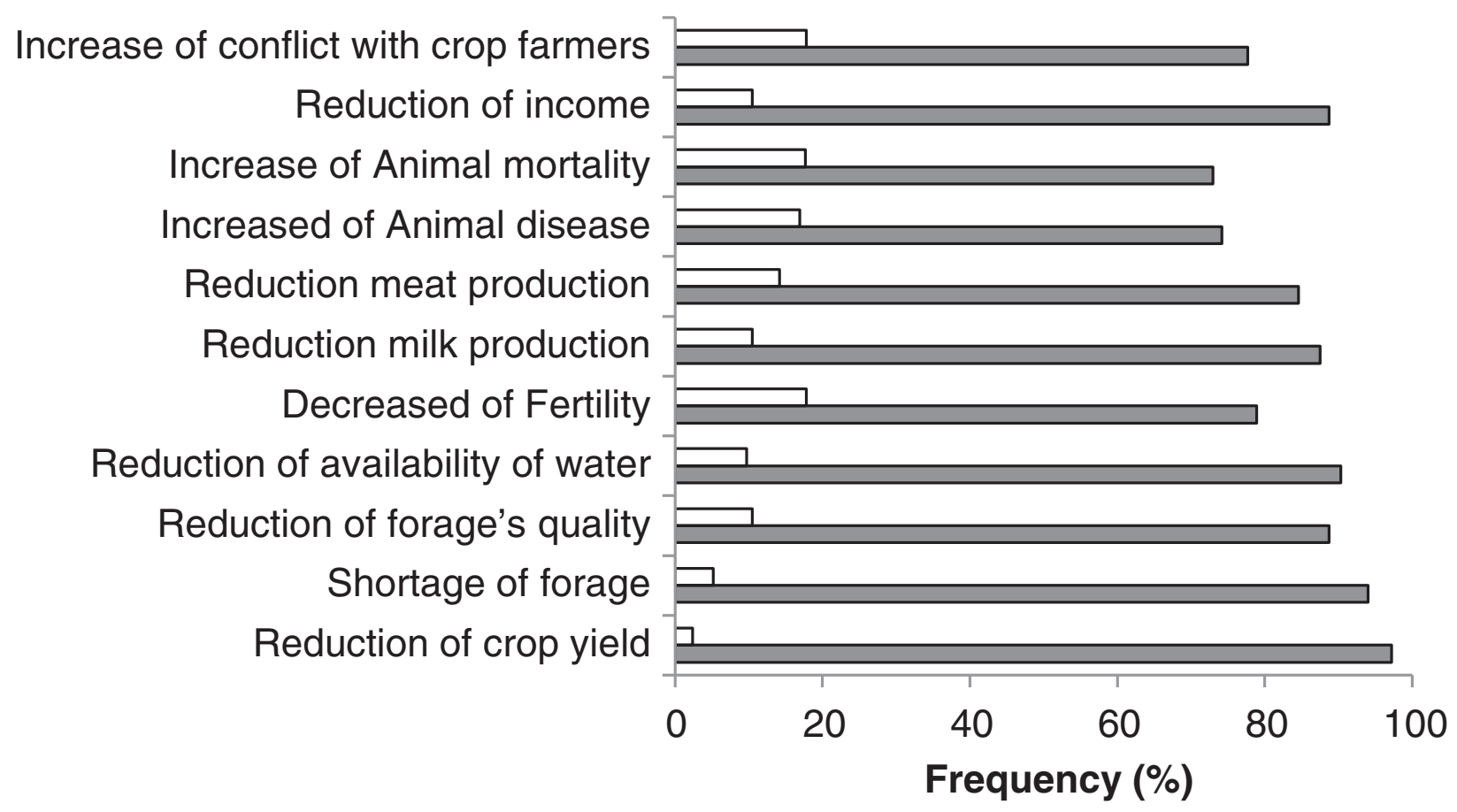

Disagree $\square$ Agree

Fig. 4 Perception of farmers $(n=248)$ about the impact of climate variability and change on livestock husbandry in Boulgou Province ( white $=$ disagree, grey $=$ agree). The responses from respondents imply that they are well aware of the impacts of climate change on livestock production

$74 \%$ and $73 \%$ of the respondents observed that livestock morbidity and mortality had increased due to increase in some vector-borne diseases. The observation by the respondents agreed with the report of Courtin et al. (2010) that within the belt of the tsetse flies (Diptera Glossinidae), the vectors that cause trypanosomiasis in both humans and livestock, had shifted by 25 to $150 \mathrm{~km}$ to the south of Burkina Faso due to rainfall variability and population density. It is worth mentioning that the answers provided by the respondents may have been influenced not only by their perception of climate change, which is the focus of this study, but also by other factors such population increase, competition for land and soil degradation that are known to have considerable impacts on livestock production.

Furthermore, the result of studies conducted in southern Sahelian and northern and southern Sudanian ecological zones of Burkina Faso by Zampaligré et al. (2013) and Kiema et al. (2013) in eastern Burkina Faso confirmed the observations made by the respondents in Boulgou Province (sub-humid zone of Burkina Faso) regarding the reduction of income and increase in conflict between livestock and crop farmers. This finding implies that changing climate patterns had affected the respondents to a great extent and have increased the vulnerability of agro-pastoralists in the study area. Sirohi and Michaelowa (2007) reported that livestock production would be severely affected in a region where increased temperature is related to decrease in rainfall.

\section{Local adaptation measures and barriers affecting their usage}

As adaptation measures (Table 5), the respondents feed livestock with crop residue $(98.4 \%)$ and concentrate feed (80.6\%), practise herd destocking (44.8\%), use woody fodder $(42.3 \%)$ and engage in off-farm activities (30.2\%), haymaking (30.1\%) and transhumance (19.8\%). Due to decreasing grazing land and high rainfall variability, livestock feed mostly on less palatable grasses available in pastures and after-harvest crop residues, which had continued to increase in Burkina Faso (Barbier et al. 2009; Zampaligré et al. 2013). Regarding the integration of livestock and crop farm activities, OECD/SWAC (2008) reported that agro-pastoralism is one of the major innovations in most Sahel countries during the last decades.

The vast majority of interviewed agro-pastoralists reported that there are inadequate training and materials for haymaking, which explained the low acceptance of this measure. The least widespread measures that were adopted by the respondents were cultivation of crop fodder species $(8.9 \%)$, change in animal species $(6.1 \%)$ and cultivation of woody fodder species $(0.8 \%)$. Kagoné (2006) described the three major obstacles affecting the 
Table 5 Descriptive statistics of the major determinants of agro-pastoralists' adaptation measures in the sub-humid zone of Burkina Faso

\begin{tabular}{|c|c|c|c|c|c|c|c|c|c|c|c|c|c|c|c|c|}
\hline \multirow[b]{3}{*}{ Adoption } & \multicolumn{16}{|c|}{ Adaptation measures } \\
\hline & \multicolumn{2}{|c|}{ Making hay } & \multicolumn{2}{|c|}{$\begin{array}{l}\text { Crop } \\
\text { residues }\end{array}$} & \multicolumn{2}{|c|}{$\begin{array}{l}\text { Concentrated } \\
\text { livestock feed }\end{array}$} & \multicolumn{2}{|c|}{ Transhumance } & \multicolumn{2}{|c|}{ Destocking } & \multicolumn{2}{|c|}{ Fattening } & \multicolumn{2}{|c|}{$\begin{array}{l}\text { Off-farm } \\
\text { activities }\end{array}$} & \multicolumn{2}{|c|}{$\begin{array}{l}\text { Woody } \\
\text { fodder }\end{array}$} \\
\hline & Yes & No & Yes & No & Yes & No & Yes & No & Yes & No & Yes & No & Yes & No & Yes & No \\
\hline Number of respondents & 74 & 172 & 244 & 4 & 200 & 48 & 49 & 199 & 111 & 137 & 58 & 190 & 75 & 173 & 105 & 143 \\
\hline Percentage of respondents & 29.8 & 69.4 & 98.4 & 1.6 & 80.6 & 19.4 & 19.8 & 80.2 & 44.8 & 55.2 & 23.4 & 76.6 & 30.2 & 69.8 & 42.3 & 57.7 \\
\hline \multicolumn{17}{|l|}{$\begin{array}{l}\text { Household characteristics: } \\
\text { mean (SD) }\end{array}$} \\
\hline Age & $\begin{array}{l}57 \\
(11)\end{array}$ & $\begin{array}{l}54 \\
(11)\end{array}$ & $\begin{array}{l}55 \\
(11)\end{array}$ & $\begin{array}{l}54 \\
(13)\end{array}$ & $\begin{array}{l}53^{\mathrm{a}} \\
(11)\end{array}$ & $\begin{array}{l}59^{\mathrm{b}} \\
(13)\end{array}$ & $\begin{array}{l}51^{a} \\
(9)\end{array}$ & $\begin{array}{l}56^{\mathrm{b}} \\
(12)\end{array}$ & $\begin{array}{l}56 \\
(13)\end{array}$ & $\begin{array}{l}54 \\
(11)\end{array}$ & $\begin{array}{l}53^{\mathrm{a}} \\
(10)\end{array}$ & $\begin{array}{l}56^{\mathrm{b}} \\
(12)\end{array}$ & $\begin{array}{l}51^{a} \\
(8)\end{array}$ & $\begin{array}{l}56^{\mathrm{b}} \\
(13)\end{array}$ & $\begin{array}{l}56 \\
(10)\end{array}$ & $\begin{array}{l}54 \\
(12)\end{array}$ \\
\hline Household size & $\begin{array}{l}17 \\
(11)\end{array}$ & $\begin{array}{l}18 \\
(12)\end{array}$ & $\begin{array}{l}17 \\
(11)\end{array}$ & $\begin{array}{l}23 \\
(24)\end{array}$ & $\begin{array}{l}18 \\
(12)\end{array}$ & $\begin{array}{l}17 \\
(11)\end{array}$ & $\begin{array}{l}17 \\
(11)\end{array}$ & $\begin{array}{l}18 \\
(12)\end{array}$ & $\begin{array}{l}18 \\
(13)\end{array}$ & $\begin{array}{l}17 \\
(10)\end{array}$ & $17(8)$ & $\begin{array}{l}18 \\
(12)\end{array}$ & $\begin{array}{l}18^{\mathrm{a}} \\
(9)\end{array}$ & $\begin{array}{l}17^{b} \\
(13)\end{array}$ & $\begin{array}{l}18 \\
(14)\end{array}$ & $\begin{array}{l}17 \\
(10)\end{array}$ \\
\hline Cattle number & $\begin{array}{l}17 \\
(25)\end{array}$ & $\begin{array}{l}20 \\
(29)\end{array}$ & $\begin{array}{l}18^{\mathrm{a}} \\
(26)\end{array}$ & $\begin{array}{l}63^{b} \\
(66)\end{array}$ & $\begin{array}{l}22^{\mathrm{a}} \\
(30)\end{array}$ & $5^{\mathrm{b}}(9)$ & $\begin{array}{l}40^{\mathrm{a}} \\
(32)\end{array}$ & $\begin{array}{l}13^{b} \\
(24)\end{array}$ & $\begin{array}{l}14^{\mathrm{a}} \\
(22)\end{array}$ & $\begin{array}{l}23^{b} \\
(31)\end{array}$ & $\begin{array}{l}14 \\
(13)\end{array}$ & $\begin{array}{l}20 \\
(31)\end{array}$ & $\begin{array}{l}12 \\
(13)\end{array}$ & $\begin{array}{l}22 \\
(32)\end{array}$ & $\begin{array}{l}18 \\
(29)\end{array}$ & $\begin{array}{l}19 \\
(27)\end{array}$ \\
\hline Sheep number & $\begin{array}{l}15 \\
(13)\end{array}$ & $\begin{array}{l}17 \\
(22)\end{array}$ & $\begin{array}{l}16 \\
(19)\end{array}$ & $\begin{array}{l}26 \\
(26)\end{array}$ & $\begin{array}{l}18^{\mathrm{a}} \\
(21)\end{array}$ & $9^{\mathrm{b}}(7)$ & $\begin{array}{l}31^{\mathrm{a}} \\
(29)\end{array}$ & $\begin{array}{l}13^{b} \\
(14)\end{array}$ & $\begin{array}{l}14^{\mathrm{a}} \\
(19)\end{array}$ & $\begin{array}{l}18^{\mathrm{b}} \\
(20)\end{array}$ & $15(9)$ & $\begin{array}{l}17 \\
(21)\end{array}$ & $\begin{array}{l}16 \\
(12)\end{array}$ & $\begin{array}{l}17 \\
(22)\end{array}$ & $\begin{array}{l}14^{\mathrm{a}} \\
(17)\end{array}$ & $\begin{array}{l}18^{\mathrm{b}} \\
(20)\end{array}$ \\
\hline Goat number & $\begin{array}{l}19 \\
(12)\end{array}$ & $\begin{array}{l}12 \\
(15)\end{array}$ & $\begin{array}{l}14 \\
(14)\end{array}$ & $\begin{array}{l}19 \\
(21)\end{array}$ & $\begin{array}{l}14 \\
(15)\end{array}$ & $\begin{array}{l}12 \\
(12)\end{array}$ & $\begin{array}{l}21^{\mathrm{a}} \\
(18)\end{array}$ & $\begin{array}{l}12^{\mathrm{b}} \\
(13)\end{array}$ & $\begin{array}{l}14 \\
(19)\end{array}$ & $\begin{array}{l}14 \\
(14)\end{array}$ & $12(8)$ & $\begin{array}{l}15 \\
(16)\end{array}$ & $\begin{array}{l}12 \\
(11)\end{array}$ & $\begin{array}{l}15 \\
(16)\end{array}$ & $\begin{array}{l}15 \\
(15)\end{array}$ & $\begin{array}{l}13 \\
(14)\end{array}$ \\
\hline
\end{tabular}

${ }_{\mathrm{a}, \mathrm{b}}$ Significant difference of row mean within the same adaptation practices (Kruskal-Wallis test, $p \leq 0.05$ )

cultivation of crop fodder species as land ownership rights, the agricultural calendar and seed availability. It has been reported that changing to other livestock species mostly occurred when the pastoralists are educated (Zampaligré et al. 2013). However, this is not the case in Boulgou Province as $96 \%$ of the heads of household interviewed were illiterates.

The diversity of the measures highlighted by the respondents is low and mostly short-term adjustments. This raises the question of what prevents respondents from adopting new technologies as adaptation measures. The analysis of constraints listed by respondents showed that water scarcity and accessibility ranked first, despite the observation that Boulgou Province is regarded as well drained by seasonal rivers. Kandji et al. (2006) and MRA (2010) demonstrated in their report that inadequate quality of fodder and water are important constraints militating against the improvement of livestock production in the Sahel region. In addition, obstructing livestock mobility routes, inadequate access to new knowledge on adaptation, and land tenure system were all ranked low but were still regarded as critical in studies by Kiema et al. (2013) and Ouédraogo et al. (2010). Most of the adaptation measures referred to in this study are adopted by the agro-pastoralists during drought periods, which they perceived to have increased. However, trend analysis of climate data for the period under study had also shown that wet days had increased alongside flood events. This has exposed further the vulnerability of the agro-pastoralists to flood events, a risk that can be minimised with appropriate assistance from relevant agencies in Burkina Faso.

\section{Determinants of farmers' adaptation measures in the} sub-humid zone of Burkina Faso

The result from the binary regression analysis is shown in Table 6. The table shows only the adaptation measures which are influenced by at least one determinant whose $p<0.05$. This table showed that sheep and goat herd size is the important determinant affecting haymaking. Farmers that own large herds of sheep were more likely to adopt haymaking during the dry season. This may be explained by the practice of fattening the animals in preparation for festive periods. The use of concentrated livestock feed is less likely to occur in farms with a large cattle size. Thus, farmers with large herds of cattle preferred to rely mostly on natural pasture by adopting transhumance $(p<0.05)$ because concentrated livestock feed is expensive in Burkina Faso (Table 5). Furthermore, the practice of transhumance in Burkina Faso depends on the household and cattle herd size (Kiema et al. 2013; Zampaligré et al. 2013). Our findings indicated that cattle herd size positively affected the choice to adopt adaptation measures such as transhumance and off-farm activities while it negatively affected concentrated livestock feed adoption (Table 6). Agro-pastoralists in our study area who own larger cattle herd size are likely to practise transhumance and engage in off-farm activities.

To minimise the risk arising from rainfall variability, seeking alternative sources of income is necessary. Engagement in off-farm activities (such as small commercial activities, mining, building, transportation or working with NGOs or with the Government) was significantly $(p<$ 0.05) influenced by the age of the household head, the household size and the cattle herd size (Table 5). The age 
Table 6 Results of the binary logistic regression analysis of factors affecting future adaptation strategies

\begin{tabular}{|c|c|c|c|c|c|c|}
\hline Predictors & $B$ & SE $\beta$ & Wald's $X^{2}$ & $d f$ & $p \leq$ & $E \beta$ (odds ratio) \\
\hline \multicolumn{7}{|l|}{ Making hay } \\
\hline Constant & 3.444 & 1.163 & 8.775 & 1 & 0.003 & 31.312 \\
\hline Sheep herd size & 0.045 & 0.016 & 7.587 & 1 & 0.006 & 1.046 \\
\hline Goat herd size & -0.090 & 0.019 & 21.957 & 1 & 0.000 & 0.914 \\
\hline Test & & & $x^{2}$ & $d f$ & $p$ & \\
\hline Overall model evaluation & & & 35.213 & 7 & 0.000 & \\
\hline Goodness of fit ${ }^{a}$ & & & 8.903 & 8 & 0.351 & \\
\hline \multicolumn{7}{|l|}{ Concentrated livestock feed } \\
\hline Constant & -3.067 & 1.570 & 3.814 & 1 & 0.051 & 0.047 \\
\hline Cattle herd size & -0.082 & 0.029 & 7.749 & 1 & 0.005 & 0.921 \\
\hline Test & & & $x^{2}$ & $d f$ & $p$ & \\
\hline Overall model evaluation & & & 38.993 & 7 & 0.000 & \\
\hline Goodness of fit ${ }^{a}$ & & & 5.413 & 8 & 0.713 & \\
\hline \multicolumn{7}{|l|}{ Transhumance } \\
\hline Constant & -0.468 & 1.374 & 0.116 & 1 & 0.733 & 0.626 \\
\hline Household size & 0.081 & 0.028 & 8.142 & 1 & 0.004 & 1.084 \\
\hline Cattle herd size & 0.022 & 0.009 & 5.561 & 1 & 0.018 & 0.978 \\
\hline Test & & & $x^{2}$ & $d f$ & $p$ & \\
\hline Overall model evaluation & & & 57.061 & 7 & 0.000 & \\
\hline Goodness of fit ${ }^{a}$ & & & 9.598 & 8 & 0.294 & \\
\hline \multicolumn{7}{|l|}{ Destocking } \\
\hline Constant & -1.555 & 0.986 & 2.489 & 1 & 0.115 & 0.211 \\
\hline Cattle herd size & 0.025 & 0.009 & 8.083 & 1 & 0.004 & 1.026 \\
\hline Test & & & $x^{2}$ & $d f$ & $p$ & \\
\hline Overall model evaluation & & & 19.186 & 7 & 0.008 & \\
\hline Goodness of fit ${ }^{\mathrm{a}}$ & & & 10.166 & 8 & 0.254 & \\
\hline \multicolumn{7}{|l|}{ Off-farm activities } \\
\hline Constant & 1.401 & 1.336 & 1.100 & 1 & 0.294 & 4.061 \\
\hline Age of household head & 0.055 & 0.018 & 9.355 & 1 & 0.002 & 1.057 \\
\hline Household size & -0.040 & 0.016 & 6.072 & 1 & 0.014 & 0.961 \\
\hline Cattle number & 0.036 & 0.014 & 6.543 & 1 & 0.011 & 1.036 \\
\hline Test & & & $x^{2}$ & $d f$ & $p$ & \\
\hline Overall model evaluation & & & 48.242 & 7 & 0.000 & \\
\hline Goodness of fit ${ }^{\mathrm{a}}$ & & & 5.221 & 8 & 0.734 & \\
\hline
\end{tabular}

aHosmer and Lemeshow goodness-of-fit test (Archer and Lemeshow 2006)

of the head of the household was found to have a positive effect in the diversification of livelihood. This result confirms the findings of other studies (Ibrahim and Onuk 2009; Zahonogo 2011). However, after a certain age, the likelihood of engaging in off-farm activities declined (Zahonogo 2011). Other studies emphasised the importance of financial capital (D'haen et al. 2014; Ibrahim and Onuk 2009). The lack of financial capital for livelihood diversification leads to migration of the youths to urban areas outside Burkina Faso. However, Table 6 confirms diversifying activities is the most likely adaptation measure to be adopted by the agro-pastoralists in the study area.

\section{Challenges and opportunities for a climate change} adaptation action plan on livestock producers in Burkina Faso For centuries, livestock producers in countries such as Burkina Faso have been adapting their production systems and livelihood to cope with the Sahel's changing environment, and societies have survived based on herd, pasture and water management (Ancey et al. 2009; 
Bonfiglioli 1988). Without doubt, the sustainability of this sector can be the impetus for improving the livelihood of majority of rural people for which it constitutes an income source. As in most West African countries, the benefits of the livestock sector are underexploited and the sector has never been a priority for the government of Burkina Faso. Additionally, until 2012, when gold exports increased to $68 \%$, the livestock sector was the country's second largest source of foreign currency (AfDB/OECD/UNDP, 2014). Prior to the establishment of the Ministry of Livestock in 1997, the impact of government, including the French colonialists, was felt mainly through the provision of veterinary services to livestock farmers in the 1950s to 1998 (Landais 1990; Tall 1999). In 1980, the livestock agency created by the French was replaced by the Ministry of Rural Development and several other Ministries in subsequent years, to the detriment of the livestock sector.

Since then, several action plans and programmes for the improvement of livestock production have been implemented; these include the Orientation Law on Pastoralism (LORP), Action Plan and Investment Programme for the Livestock Farming Sector (PAPISE) and National Policy for Sustainable Livestock Development (PNDEL). Though these programmes and policies support the development of the livestock sector, they do not specifically address the issue of climate change adaptation. The Ministry of Livestock Resources is politically marginalised with inadequate funding and support (Gning 2005). The livestock sector received only $2 \%$ to $11 \%$ of the annual budgets allocated to the primary sector, compared to $36 \%$ to $50 \%, 18 \%$ to $38 \%$ and $6 \%$ to $26 \%$ for crop production, water and environment, respectively (MRA Ministère des Ressources Animales 2010).

Against this background of inadequate funding for the sector, theoretical model simulations of the climate change in Burkina Faso projected that by 2025, an average temperature increase of $0.8{ }^{\circ} \mathrm{C}$ and a relative decrease of $-3.4 \%$ in rainfall are likely coupled with a very strong seasonal and inter-annual variability (PANA 2007). Regardless of this additional climatic challenge, local stakeholders in the sector are expected to sustainably increase production and income. Consequently, a wellcoordinated modification of livestock management practices through appropriate pro-poor adaptation measures is very necessary. However, the awareness of climate change in the livestock sector is generally very low; hence, appropriate information is paramount. In addition, the organisational structure that could facilitate the establishment of a 'collective identity' to serve this purpose is limited by ethnicity, elitism, irresolute government and project-based interventions.

Regrettably, livestock farmers are yet to attain the political clout that could influence government livestock policies. The two prominent pre-existing potential lobby groups, namely Peri-urban Professional Associations and the Provincial Herders Union, that could collaborate to push for appropriate adaptation policies address issues that are not all-encompassing. Furthermore, the vastness of the terrain, geographic dispersion (of communication and transportation) and diversity of livestock production systems hampers the coordination of their activities. Besides these two groups, the most vulnerable livestock producers are usually involved in subsistence farming and are too poor and politically insignificant; this is typical in Boulgou as most of the agro-pastoralists do not belong to any herders association. They are less likely to influence national or sectoral policies. Juana et al. (2013) stated that climate change adaptation requires access to information and utilisation of climate change and adaptation technologies, as well asaccess to affordable credit for implementation of strategies.

Using Boulgou Province as a case study, adaptation measures used by agro-pastoralists are shown in Table 5 . These measures could inform people-centred livestock action plans or policies. The agro-pastoralists specifically indicated that the capital-intensive nature of haymaking and access to concentrated livestock feed are major challenges in adopting these two measures. Under the PAPISE programme, the government provided increased access to natural hay, crop residues and concentrate feeds and embarked upon vaccination services. This contributed to the growth in livestock production in 2013 (AfDB/OECD/UNDP, 2014).

In low-income agrarian countries, livestock policies are usually driven by concerns for the large masses of rural poor, through adopting technology development and promotion (FAO 2006). However, these policies should be incorporated within a broader policy and institutional framework that involves not just technocrats, but also stakeholders such as the Peri-urban Professional Associations and the Provincial Herders Union, nongovernmental organisations (NGOs) and inter-ministerial representatives that can link and identify relevant policies beneficial to the livestock sector (FAO 2009). Dorward et al. (2004a, b) and Pica-Ciamarra (2005) recommended that such policies consist of three major components that address the constraints faced by smallholder farmers: first, adequate management of the basics of livestock production, e.g. access to land, feed, infrastructure and water; second, enhanced livestock productivity, e.g. access to animal health services, credit facilities, information and output markets; and third, sustained livestock productivity and competitiveness, e.g. research output and environmental protection.

PAPISE, the operational action plan of PNDEL of Burkina Faso for the period 2010 to 2015, appears to address these three components. It is recommended 
that PNDEL be reformed to accommodate an action plan for implementing climate change adaption strategies in view of the projected changes in climate for Burkina Faso. In collaboration with the stakeholders, new strategies or those already being practised can be further prioritised using appropriate socio-economic criteria (FAO 2012). Although no country has elaborated and implemented an all-encompassing livestock sector development strategy (FAO 2012), Burkina Faso, by learning from case studies like Boulgou Province, can improve the food security and poverty situation in the country, while tackling the impacts of climate change simultaneously.

\section{Conclusion}

The statistical analysis of temperature data of Boulgou Province showed increasing temperatures of $+0.20{ }^{\circ} \mathrm{C}$ and $+0.27{ }^{\circ} \mathrm{C}$ per decade for maximum and minimum temperatures, respectively. Regarding the observed annual rainfall amount, the high degree of temporal variability showed a slightly increasing trend. The 95th percentile of rainfall and the cumulative 5-day rainfall are also increasing. Rainfall is one of the main agroclimatic parameters in the Sahel region, so the onset, cessation and LRS were also analysed. We found that these parameters had an increasing trend.

In assessing the perception of climate change, most of the respondents' observations corroborated the meteorological data. One major area of disagreement between the perception of respondents and scientific data is in the rainfall amount and LRS. The climate data analysis indicated an increase in LRS, but the respondents observed a decrease. On the contrary, both respondents' perception and scientific evidence agreed that onset of rains in Boulgou Province are late. This is a very critical change because of its impact on the availability of fresh forage after a lengthy dry season.

To sustain livestock production, the respondents adopted some local adaptation measures that primarily involved the use of crop residues and concentrate feeds. Other less popular measures were adopted by the respondents, such as planting different woody and crop fodder species and changing livestock species. The age of the household head, the household size and livestock herd size are significant predictors for future acceptance of some adaptation measures, such as transhumance, herd destocking, engaging in off-farm activities and so on. Therefore, for a successful implementation of adaptation measures identified by Boulgou agro-pastoralists in the sub-humid zone of Burkina Faso, among others, an all-encompassing climate change action plan needs to be incorporated into a reviewed National Policy for Sustainable Livestock Development, as it reaches its terminal duration of 2015.

\section{Competing interests}

The authors declare that they have no competing interests.

\section{Authors' contributions}

SK is the young scientist that carried out the research under the mentorship of the under listed and prepared the draft manuscript for further input. AA is the primary mentor of the researcher. She supervised the research, helped with the proposal preparation and defence and made substantial input to the manuscript. AK assisted substantially with the field work as a co-supervisor and reporting of the outcome of the field work in Burkina Faso and contributed to the preparation of the manuscript. NZ contributed substantially in the statistical analysis undertaken in the research and also made contributions to the manuscript. IS assisted during preparation of the research report, subjected the work to antiplagiarism software and helped with manuscript corrections. All the authors have read and approved the final manuscript.

\section{Authors' information}

SAK has a Master's degree in Climate Change and Adapted Land Use and obtained a first degree in Rural Development Engineering, specialising in animal husbandry. She currently is employed by the Ministry of Livestock Resources of Burkina Faso.

$\mathrm{AAO}$ is a PhD holder in applied remote sensing with emphasis on geographical sciences including climate change. She is employed by the Federal University of Technology, Minna, Nigeria, but seconded to coordinate the Climate Change and Adapted Land Use programme in West African Science Service Center on Climate Change and Adapted Land Use. AK is a PhD holder in animal production with focus in animal nutrition, and exploitation and management of pasture. He is a researcher in the National Scientific and Technological Research Centre (CNRST).

$\mathrm{NZ}$ is a PhD holder in agricultural sciences specialised in pastoral livestock in West Africa with focus on (i) the interactions between pastoral livestock and savannah ecosystems in West Africa as determined by livelihood strategies of pastoralist households; (ii) climate change impacts on natural resource management and ecosystem services, and appropriate adaptation and mitigation strategies in West Africa; and (iii) modelling of livestock herd movements and grazing behaviour and their use of forage resources using GIS and remote sensing tools.

IS is a research coordinator with the Climate Change and Adapted Land Use programme in the West African Science Service Center on Climate Change and Adapted Land Use of the Federal University of Technology, Minna.

\section{Acknowledgements}

This research was funded by the German Federal Ministry of Education and Research (BMBF) through the West African Science Service Center on Climate Change and Adapted Land Use (WASCAL). We are also grateful to the Meteorology Department of Burkina Faso for providing the climate data used in the study, and finally, we appreciate the cooperation and assistance of livestock extension service employees and the farmers of Boulgou Province who agreed to participate in the survey.

\section{Author details}

${ }^{1}$ Master Research Programme on Climate Change and Adapted Land Use, West African Science Service Center on Climate Change and Adapted Land Use, Federal University of Technology, Gidan Kwano Campus, PMP 65, Minna, Niger State, Nigeria. ${ }^{2}$ Institut de I'Environnement et de Recherches Agricoles (INERA), 04 BP 8645, Ouagadougou 04, Burkina Faso. ${ }^{3}$ Institut de I'Environnement et de Recherches Agricoles (INERA), Direction Regionale de Recherches Environnementales et Agricoles du Sahel (DRREA/Sahel), BP 80, Dori, Burkina Faso.

Received: 4 March 2015 Accepted: 29 July 2015

Published online: 24 August 2015

\section{References}

Adesina, AA, and MM Zinnah. 1993. Technology characteristics, farmer perceptions and adoption decisions: a Tobit model application in Sierra Leone. Agricultural Economics 9: 297-311.

AfDB/OECD/UNDP, 2014. African Economic Outlook (2014) African Development Bank, Organisation for Economic Co-operation and Development, United Nations Economic Commission for Africa. Paris: OECD Publishing. 
Aguilar, E, AA Barry, M Brunet, L Ekang, A Fernandes, M Massoukina, J Mbah, A Mhanda, DJ do Nascimento, TC Peterson, O Thamba Umba, M Tomou, and X Zhan. 2009. Changes in temperature and precipitation extremes in western central Africa, Guinea Conakry, and Zimbabwe, 1955-2006. Journal of Geophysical Research 114: d02115. doi:10.1029/2008jd011010.

Akponikpè, PBI, P Johnston, and KE Agbossou. 2010. ICID + 18 2nd International Conference: Climate, Sustainability and Development in Semi-arid Regions August 16-20, 2010. Brazil: Fortaleza - Ceará. Farmers' perception of climate change and adaptation strategies in sub-Saharan West-Africa.

Allé, CSYU, VP Vissoh, H Guibert, KE Agbossou, AA Afouda. 2013. Relation entre perceptions paysannes de la variabilité climatique et observations climatiques au Sud- Bénin. Vol 13 No 3. http://vertigo.revues.org/14361. Accessed 27 September 2013

Ancey, V, A Ickowicz, I Touré, A Wane, and AT Diop. 2009. La vulnérabilité pastorale au Sahel: portée et limites des systèmes d'alerte basés sur des indicateurs. In L'élevage, richesse des pauvres: Stratégies d'éleveurs et organisations sociales face aux risques dans les pays du Sud, ed. G Duteurtre and B Faye, 117-132. France: Ed. Quae: Versailles.

Archer KJ, Lemeshow S (2006) Goodness-of-fit test for a logistic regression model fitted using survey sample data. Stata J 6:97-105.

Barbier, B, H Yacouba, H Karambiri, M Zorome, and B Some. 2009. Human vulnerability to climate variability in the Sahel: farmers' adaptation strategies in northern Burkina Faso. Environmental Management 43: 790-803.

Bonfiglioli, AM. 1988. Dudal: histoire de famille et histoire de troupeau chez un groupe de WoDaaBe du Niger. Cambridge, UK: Cambridge University Press.

Courtin, F, JB Rayaissé, I Tamboura, O Serdébéogo, Z Koudougou, P Solano, and I Sidibé. 2010. Updating the northern tsetse limit in Burkina Faso (1949-2009): Impact of global change. International Journal of Environmental Research and Public Health 7: 1708-1719.

D'haen, SAL, JØ Nielsen, and EF Lambin. 2014. Beyond local climate: Rainfall variability as a determinant of household nonfarm activities in contemporary rural Burkina Faso. Climate and Development 6(2): 144-165. doi:10.1080/ 17565529.2013 .867246$.

Dorward, A, J Kydd, J Morrison, and I Urey. 2004a. A policy agenda for pro-poor agricultural growth. World Development 32(1): 73-89.

Dorward, A, S Fan, J Kydd, H Lofgren, J Morrison, C Poulton, N Rao, L Smith, H Tchale, S Thorat, I Urey, and P Wobst. 2004b. Institutions and policies for pro-poor agricultural growth. Development Policy Review 22(6): 611-622.

ECOWAS-SWAC/OECD/CILSS. 2008. Climate and climate change. The atlas on regional integration in West Africa, Environment series. http://WWW.atlas-westafrica.org. Accessed 10 January 2014.

FAO. 2006. Livestock's long shadow: Environmental issues and options, by $\mathrm{H}$. Steinfeld, P. Gerber, T. Wassenaar, V. Castel, M. Rosales and C. de Haan. Rome: FAO.

FAO. 2009. In Background paper for the FAO Committee on Agriculture, 21st Session. Rome: FAO. Livestock policy and institutional change for poverty reduction.

FAO. 2012. Livestock sector development for poverty reduction: An economic and policy perspective - Livestock's many virtues, by J. Otte, A. Costales, J. Dijkman, U. Pica- Ciamarra, T. Robinson, V. Ahuja, C. Ly and D. Roland-Holst, 161. Rome: FAO.

Folland, CK, TN Palmer, and DE Parker. 1986. Sahel rainfall worldwide sea temperatures, 1901-85. Nature 320: 602-606.

Galvin, KA, PK Thornton, RB Boone, and J Sunderland. 2004. Climate variability and impacts on East African livestock herders: The Maasai of Ngorongoro Conservation Area, Tanzania. African Journal of Range and Forage Science 21(3): 183-189.

Garbutt, DJ, RD Stern, MD Denett, and J Elston. 1981. A comparison of the rainfall climate of eleven places in West Africa, using a two-part model for daily rainfall. Archives for Meteorology, Geophysics, and Bioclimatology 29: 137-155.

Giannini, A, R Saravanan, and P Chang. 2003. Oceanic forcing of Sahel rainfall on interannual to interdecadal time scales. Science 302(5647): 1027-1030.

Haarsma, R, F Selten, N Weber, and M Kliphuis. 2014. Sahel rainfall variability and response to greenhouse warming. Geophysical Research Letters 32: 1-4. http://portal.iri.columbia.edu/ alesall/ouagaCILSS/articles/ haarsma_grl2005.pdf.

Hadgu, G, K Tesfaye, G Mamo, and B Kassa. 2013. Trend and variability of rainfall in Tigray, Northern Ethiopia: Analysis of meteorological data and farmers' perception. Academia Journal of Environment Science 1(8): 159-171.

Ibrahim, HI, and GE Onuk. 2009. Analysis of rural non-farm diversification among farming households in Doma area of Nasarawa State. Nigeria. PAT 5(1): 49-54. ISSN: 0794-5213.
INSD (Institut National des Statistiques et de la Demographie). 2013. Annuaire statistique 2011, 420.

IPCC. 2007. Climate change 2007: Impacts, adaptations and vulnerability. In Contribution of Working Group II to the Fourth Assessment Report of the IPCC, ed. ML Parry, OF Canziani, JP Palutikof, PJ Van der Linden, and CE Hanson, 976. Cambridge, UK: Cambridge University Press.

Jain, SK, and V Kumar. 2012. Trend analysis of rainfall and temperature data for India. Current Science 102(1): 37-49.

JMA (Japan Meteorological Agency), and JMA (Japan Meteorological Agency). 2011. Global temperature in 2010. In Tokyo Climate Center News. http://ds.data.jma.go.jp/tcc/tcc/news/tccnews23.pdf. Accessed 31 May 2014.

Juana, JS, Z Kahak, and FN Okurut. 2013. Farmers' perceptions and adaptations to climate change in sub-Sahara Africa: A synthesis of empirical studies and implications for public policy in African agriculture. Journal of Agricultural Science 5(4): 121.

Kagoné, H. 2006. Country pasture/forage resource profile - Burkina Faso. Burkina Faso: FAO. http://www.fao.org/ag/AGP/AGPC/doc/counprof/PDF\%20files/ Burkina-English.pdf. Accessed 30 May 2013.24.

Kandji, ST, L Verchot, and J Mackensen. 2006. Climate change and variability in the Sahel region: Impacts and adaptation strategies in the agricultural sector, 58. http://www.unep.org/. Accessed 5 April 2014.

Karabulut, M, M Gürbüz, and H Korkmaz. 2008. Precipitation and temperature trend analyses in Samsun. Journal International Environmental Application \& Science 3(5): 399-408.

Kiema, A, L Some, BH Nacro, H Compaore, H Kagone, CS Ypale Kpoda, and GT Bambara. 2013. Stratégies d'adaptation des éleveurs de la zone Est du Burkina Faso aux effets des changements climatiques; Agronomie Africaine Numéro spécial (6) sur les changements climatiques, 67-79.

Klein Tank, AMG, FW Zwiers, and X Zhang. 2009. Climate data and monitoring. In Guidelines on analysis of extremes in a changing climate in support of informed decisions for adaptation. World Meteorological Organization, WCDMP-No. 72.

Landais, E. 1990. Sur les doctrines des veterinaires coloniaux francais en Afrique noire. Cahier des Sciences Humaines 26(1-2): 33-71.

Lodoun, T, A Giannini, PS Traore, L Some, M Sanon, M Vaksmann, and J Millogo- Rasolodimby. 2013. Changes in seasonal descriptors of precipitation in Burkina Faso associated with late 20th century drought and recovery in West Africa. Environmental Development 5: 96-108. http://dx.doi.org/10.1016/j.envdev.2012.11.010.

Lorenzoni, I, and NF Pidgeon. 2006. Public views on climate change: European and USA perspectives. Climatic Change 77: 73-95.

Ly, M, ST Traore, A Alhassane, and B Sarr. 2013. Evolution of some observed climate extreme in the West African Sahel. Weather and Climate Extreme 1(2013): 19-25.

Maikano, I. 2006. Generate prototype WCA recommendation maps for selected sorghum (8) and millet (8) cultivars based on updated end-of-season dates (PRODEPAM, activity). In Raport de stage. Institut International de Recherche sur les Cultures des Zones tropicales semi-arides (ICRISAT/Bamako).

McCarthy, J, OF Canziani, NA Leary, DJ Dokken, and C White. 2001. Climate change 2001: Impacts, adaptation, and vulnerability. In Contribution of Working Group II to the Third Assessment Report of the Intergovernmental Panel on Climate Change. Cambridge: Cambridge University Press.

MEF (Ministère de l'économie et de finances). 2002. Monographie de la province du Boulgou, 112.

MRA. 2010. Plan d'Actions et Programme d'Investissements du sous- secteur de I'Elevage (PAPISE) 2010-2015 du Ministère des Ressources Animales du Burkina Faso.

MRA (Ministère des Ressources Animales). 2010. Politique Nationale de Développement Durable de l'Elevage (PNDEL) au Burkina Faso, 201.

NASA. 2011. NASA research finds 2010 tied for warmest year on record. http://www.giss.nasa.gov/research/news/20110112. Accessed 31 May 2014.

Nenwiinia, S, and TA Kabanda. 2013. Trends and variability assessment of rainfall in Vhembe South Africa. Journal of Human Ecology 42(2): 171-176.

New, M, B Hewitson, DB Stephenson, A Tsiga, A Kruger, A Manhique, B Gomez, CAS Coelho, DN Masisi, E Kululanga, E Mbambalala, F Adesina, H Saleh, J Kanyanga, J Adosi, L Bulane, L Fortunata, ML Mdoka, and R Lajoie. 2006. Evidence of trends in daily climate extremes over Southern and West Africa. Journal of Geophysical Research 111, D14102. doi:10.1029/2005JD006289.

NOAA. 2011. National Climatic Data Center, State of the Climate: Annual 2010 report - Global analysis. Published online January 2011 http://www.ncdc.noaa.gov. Accessed 31 May 2014. 
OECD/SWAC. 2008. In Note prepared for the high level conference on world food security: The challenges of climate change and bioenergy. Rome: OECD/SWAC. Climate change and agro pastoral practices in the Sahel region.

Ouédraogo, M, Y Dembélé, and L Somé. 2010. Perceptions et stratégies d'adaptation aux changements des précipitations: cas des paysans du Burkina Faso. Sécheresse 21(2): 87-96.

PANA. 2007. Programme d'Action Nationale d'Adaptation à la variabilité et aux changements climatiques du Burkina Faso, Ministère de l'environnement et du cadre de vie du Burkina Faso, 76

Pica-Ciamarra, U. 2005. Livestock policies for poverty alleviation: Theory and practical evidence from Africa, Asia and Latin America. In FAO-PPLPI Working Paper No. 27. Rome: FAO.

Pinto, J, C Bonacic, C Hamilton-West, J Romero, and J Lubroth. 2008. Climate change and animal diseases in South America. Revue scientifique et technique (International Office of Epizootics) 27(2): 599-613. ISSN 0253-1933.

Safari, B. 2012. Trend analysis of the mean annual temperature in Rwanda during the last fifty two years. Journal of Environmental Protection 3: 538-551. http://dx.doi.org/10.4236/jep.2012.36065 (http://www.SciRP.org/journal/jep).

Sarr, B. 2012. Present and future climate change in the semi-arid region of West Africa: A crucial input for practical adaptation in agriculture. Atmospheric Science Letters 13: 108-112. doi:10.1002/asl.368.

Sarr, B, L Kafando, and S Atta. 2011. Identification des risques climatiques de la culture du maïs au Burkina Faso. International Journal of Biological and Chemical Sciences 5(4): 1659-1675. http://ajol.info/index.php/ijbcs. Accessed 5 October 2013.

Scholtz, MM, C McManus, KJ Leeuw, H Louvandini, L Seixas, CB De Melo, A Theunissen, and FWC Neser. 2013. The effect of global warming on beef production in developing countries of the southern hemisphere. Natural Science 5(1A): 106-119.

Seo, SN, and R Mendelsohn. 2006. Climate change impacts on animal husbandry in Africa: A Ricardian analysis. In CEEPA Discussion Paper No. 9, Centre for Environmental Economics and Policy in Africa. South Africa: University of Pretoria.

Silvestri, S, E Bryan, C Ringler, M Herrero, and B Okoba. 2012. Climate change perception and adaptation of agro-pastoral communities in Kenya. Regional Environmental Change 12: 791-802. doi:10.1007/s10113-012-0293-6.

Sirohi, S, and A Michaelowa. 2007. Sufferer and cause: Indian livestock and climate change. Climatic Change 85: 285-298. doi:10.1007/s10584-007-9241-8.

Somé, L, and MVK Sivakumar. 1994. Analyse de la longueur de la saison culturale en fonction de la date de début des pluies au Burkina Faso. INERAOuagadougou/ ICRISAT-Niger, 43.

Tall, M. 1999. Contribution sur l'evolution de I"elevage au Burkina Faso de 1895 a 1985. In Burkina Faso: Cent Ans d'Histoire, 1895-1995, ed. YG Madiega and O Nao. Paris: Karthala.

Thornton, P, M Herrero, A Freeman, O Mwai, E Rege, P Jones, and J McDermott. 2007. Vulnerability, climate change and livestock - Research opportunities and challenges for poverty alleviation, vol. IV, 1st ed. Nairobi, Kenya: International Livestock Research Institute (ILRI). SAT J.

Thornton, PK, J van de Steeg, A Notenbaert, and M Herrero. 2009. The impacts of climate change on livestock and livestock systems in developing countries: A review of what we know and what we need to know. Agricultural Systems 101: 113-127.

Vose, RS, DR Easterling, and B Gleason. 2005. Maximum and minimum temperature trends for the globe: An update through 2004. Geophysical Research Letters 32, L23822.

Wang, S, and RR Gillies. 2011. Observed change in Sahel rainfall, circulations, African easterly waves, and Atlantic hurricanes since 1979. Internationa Journal of Geophysics 2011: Article ID 259529 14. doi:10.1155/2011/259529.

Zahonogo, P. 2011. Determinants of non-farm activities participation decisions of farm households in Burkina Faso. Journal of Development and Agricultural Economics 3(4): 174-182.

Zampaligré, N, LH Dossa, and E Schlecht. 2013. Climate change and variability: Perception and adaptation strategies of pastoralists and agro-pastoralists across different zones of Burkina Faso. Regional Environmental Change 14(5): 532

Zhang, X, and F Yang. 2004. RClimDex (1.0) user guide. In Climate research branch environment Canada. Ontario, Canada: Downsview.

Gning, MC. 2005. Navigating the livestock sector: The political economy of livestock policy in Burkina Faso. Pro-Poor Livestock Policy Initiative, Working Paper No. 28, 43

\section{Submit your manuscript to a SpringerOpen ${ }^{\circ}$ journal and benefit from:}

- Convenient online submission

- Rigorous peer review

- Immediate publication on acceptance

- Open access: articles freely available online

- High visibility within the field

- Retaining the copyright to your article

Submit your next manuscript at $>$ springeropen.com 